\title{
Evaluation of antimicrobial potential and cytotoxic of Pouteria venosa species
}

\author{
Raíssa Fernanda Evangelista Pires dos Santos ${ }^{1}$, Isabelle Souza de Mélo Silva Silva ${ }^{2}$, Eleci Adriano Hendges ${ }^{3^{*}}$, \\ Andressa Letícia Lopes da Silva', Andriele Mendonça Barbosa ${ }^{2}$, Klebson Silva Santos ${ }^{2}$, Renata Rego de Souza ${ }^{2}$, \\ Thais Honório Lins ${ }^{1}$, Regina Célia Santos Sales Verissimo', Francine Ferreira Padilha², \\ Eliane Aparecida Campesatto ${ }^{4}$, Maria Lysete de Assis Bastos ${ }^{1}$
}

From 5th Congress of the Brazilian Biotechnology Society (SBBIOTEC)

Florianópolis, Brazil. 10-14 November 2013

\section{Background}

The use and research of medicinal plants in Brazil have as allies the great plant diversity and low cost associated with treatment [1]. The popular usage relates to the species of the family Sapotaceae which reports antibacterial, antifungal, antiviral, antitumor, analgesic, antipyretic, antiinflammatory, and others [2]. It was shown that the species of genus Pouteria, belonging to the Sapotaceae family, have proven biological activities, it is cited Pouteria caimito with antioxidant and photoprotection activity against UVA and UVB; Pouteria ramiflora with antinociceptive, antiinflammatory, antioxidant, photoprotection activity (against UVA and UVB), antimicrobial activity and toxicity against larvae of Brine Shrimp, and Pouteria torta with antimicrobial and antifungal activity [3]. Phytochemical studies performed with species of Sapotaceae have revealed the presence of alkaloids, flavonoids, terpenoids, benzenoids, phenylpropanoids and Lapachol, responsible for large spectrum of biological activities [4]. Since were reported promising biological activities of the genus Pouteria, belonging to the Sapotaceae family, and their constituents, and considering that the species of Pouteria venosa, known as "tuturubá, leiteiro, Bapeba, Sapota black", has not yet defined its antimicrobial activity, aimed to evaluate the antimicrobial and cytotoxic potential in view of the bacterial and fungal infections control.

\section{Methods}

In vitro experimental study, conducted at the Research Laboratory of Wound Care at Federal University of

\footnotetext{
${ }^{3}$ Empresa Brasileira de Pesquisa Agropecuária, Av. Beira Mar, 3250, Jardins, Aracaju, Sergipe, CEP 49025-040, Brasil

Full list of author information is available at the end of the article
}

\begin{abstract}
Alagoas. It was evaluated four fractions and crude extract parts of the species Pouteria venosa named as samples A, B, C, D and E. Antimicrobial activity was determined by microbial sensitivity tests, the method of disk diffusion and broth microdilution method for determination of minimum inhibitory concentration (MIC). It was used 15 strains of microorganisms, among them Gram-positive and Gram-negative bacteria and fungi like Candida albicans, Saccharomyces cerevisiae and Aspergillus brasiliensis. Distributed by American Type Cell Cellection. Was obtained to evaluate the cytotoxicity by means of Metiltetrazolium colorimetric method which investigated the cell viability front of the samples tested.
\end{abstract}

\section{Results and conclusions}

The samples demonstrated antimicrobial activity in eight of the fifteen microorganisms evaluated in the disk diffusion test. Three of Gram-positive bacteria: Staphylococcus aureus, Staphylococcus epidermidis, Streptococcus pneumoniae, and five Gram-negative bacteria: Pseudomonas aeruginosa, Shigella flexneri, Proteus mirabilis, Acinetobacter calcoaceticus and Enterobacter aerogenes. Samples A, B and C showed high antibacterial potential front S. aureus, S. epidermidis, S. pneumoniae and $P$. aeruginosa (inhibition zones $\geq 14$ ). The results obtained by determination of the MIC of these strains showed that the fraction of sample $\mathrm{C}$ was considered with better antimicrobial activity, inhibiting microbial growth at concentrations between 1000 and $250 \mu \mathrm{g} \mathrm{mL}$ 1 . These findings corroborate with the literature, since the species Pouteria torta, Pouteria pallida e Pouteria ramiflora, also showed antimicrobial activity against these microorganisms $[3,5]$. The fungi evaluated were not sensitive to the Pouteria venosa samples. Sample C 
was considered non-toxic at the concentration of $200 \mu \mathrm{g}$ $\mathrm{mL}-1$, and is considered a promising route of preclinical in vivo. It emphasized the importance of the outcomes from the perspective of development and innovation of new therapeutic alternatives in infection control.

\section{Acknowledgements}

Brazilian Ministry of Science and Technology, Federal University of Alagoas, University Tiradentes.

\section{Authors' details}

'Laboratório de Pesquisa em Tratamento de Feridas, Universidade Federal de Alagoas, Campus A. C. Simões, Av. Lourival Melo Mota, s/n, Cidade Universitária, Maceió, Alagoas, CEP 57072-900, Brasil. ²Instituto de Tecnologia e Pesquisa, Universidade Tiradentes - Av. Murilo Dantas, 300, Farolândia, Aracaju, Sergipe, CEP 49032-490, Brasil. ${ }^{3}$ Empresa Brasileira de Pesquisa Agropecuária, Av. Beira Mar, 3250, Jardins, Aracaju, Sergipe, CEP 49025-040, Brasil. ${ }^{4}$ Laboratório de Farmacologia e Imunidade, Universidade Federal de Alagoas, Campus A. C. Simões, Av. Lourival Melo Mota, s/n, Cidade Universitária - Maceió, Alagoas, CEP 57072-900, Brasil.

Published: 1 October 2014

\section{References}

1. Santos RL, Guimaraes GP, Noble MSC, Portela AS: Analysis of phytotherapy as integrative practice in the National Health System. Brazilian Journal of Medicinal Plants 2011, 13(4):486-491.

2. Silva CAM, Simeoni LA, Silveira D: Genus Pouteria: Chemistry and biological activity. Brazilian Journal of Pharmacognsosy 2009, 19(2A):501-509.

3. Condessa MB: Evaluation of antioxidant activity of allelopathic and medicinal plants. Faculty of Science and Health Dissertation (Master in Health Sciences) - Graduate Program in Health Sciences, University of Brasilia, Brasília; 2011, $101 p$

4. Montenegro LHM, Oliveira PES, Preserve LM, Rock EMM, Brito AC, Araujo RM, Trevisan MTS, Lemos RPL: Terpenoids and evaluation of antimalarial potential, larvicide, antiradical and anticholinesterase Pouteria venosa (Sapotaceae). Brazilian Journal of Pharmacognosy 2006, 16(Suppl. 0):611-617.

5. Boleti AP, Freire MD, Coelho MB, Silva WD, Baldasso PA, Gomes VM, Marangoni S, Novello JC, Macedo ML: Insecticidal and antifugal activity of a protein from Pouteria torta seeds with lectin-like properties. Journal of Agriculturral and Food Chemistry 2007, 55(7):2653-2658.

doi:10.1186/1753-6561-8-S4-P6

Cite this article as: dos Santos et al:: Evaluation of antimicrobial potential and cytotoxic of Pouteria venosa species. BMC Proceedings 2014 8(Suppl 4):P6.

\section{Submit your next manuscript to BioMed Central and take full advantage of:}

- Convenient online submission

- Thorough peer review

- No space constraints or color figure charges

- Immediate publication on acceptance

- Inclusion in PubMed, CAS, Scopus and Google Scholar

- Research which is freely available for redistribution

Submit your manuscript at www.biomedcentral.com/submit
Ciomed Central 